ing the same fall migration to determine whether the pattern of migration of some of the thrushes, vireos, warblers and sparrows is the same as the pattern thought to occur on the basis of visual observations. As Nero (1961) points out, not only do poor weather conditions for migration have to be present to produce a kill at tall towers, but large numbers of birds must be migrating at the same time.

I am very grateful for the assistance of those people mentioned in the report who helped collect and identify the specimens found at the various towers and also to David R. M. Hatch and Harold V. Hosford for providing literature related to this subject.

\section{LITERATURE CITED}

Belcher, Margaret, A. Binnie, and Betty Binnie. 1966. The 1965 fall warbler migration at Regina. Blue Jay, $24: 10$.

Feehan, J. 1963. Destruction of birdlife in Minnesota-Sept. 1963. II. Birds killed at the Ostrander television tower. Flicker, 35: 111.
Green, Janet C. 1963. Destruction of birdlife in Minnesota - Sept. 1963. III. Notes on kills at Duluth on September 18/19. Flicker, $35: 112$.

Gollop, M. A. 1965. Bird migration collision casualties at Saskatoon. Blue Jay, 23:15.

Hosford, H. V. 1962. Migrant bird casualties at TV towers. Natural History Society of Manitoba. Ornithology Section Newsletter No. 1. Summer: 5. Mimeo.

Janssen, R. B. 1963 a. Destruction of birdlife in Minncsota - Sept. 1963. I. Birds killed at the Lewisville television tower. Flicker, $35: 110$.

Janssen, R. B. 1963b. Destruction of birdlife in Minnesota - Sept. 1963. V. Television towers in Minnesota. Flicker, $35: 113$.

Kemper, C. A. 1959. More TV tower destruction. Passenger Pigeon, $21: 135$.

Lahrman, F. W. 1959. TV tower casualty list. Blue Jay, $17: 142$.

Lahrman, F. [W.] 1962. Fall migration TV tower kills, 1962 . Blue Jay, $20: 152$.

Lahrman, F. W. 1965. Regina and Lumsden TV tower bird mortalities, 1964. Blue Jay, $23: 18$.

Nero, R. W. 1961. Regina TV tower bird mortalities - 1961. Blue Jay, $19: 160$.

Nero, R. W. 1962. Regina TV tower mortality, May 11-12, 1962. Blue Jay, $20: 151$.

Peterson, Mrs. A. W. 1963. Destruction of birdlife in Minnesota - Sept. 1963. IV. Birds killed at Park Rapids. Flicker, 35:113.

Velie, Elizabeth D. 1963. Report of a survey of bird casualties at television towers, ceilometers, and other obstructions. Flicker, $35: 79$.

Williams, G. G. 1950. Weather and spring migration. Auk, $67: 52$.

\title{
SIXTH ANNUAL MAY BIRD CENSUS, REGINA
}

The concerted efforts of 41 people in six parties resulted in the tallying of 144 species of birds (with an estimated total of 21916 individual birds seen) in Regina's annual May Bird Census, May 15, 1966, in an area constituting a circle of 30 -miles diameter around the city of Regina. Apart from the comparative picture of spring migration that this yearly count gives, it is considered by the sponsoring Regina Natural History Society to be worthwhile as a social and educational activity of the club. Any interested members of the Society are invited to participate, and this brings many who can join the party for only part of the day, and some who are relatively inexperienced bird watchers. Many of the latter, after scouring the country for all or part of the long (6:00 a.m. to dusk) day with avid "listers", are able to say that they saw a bird for the first time.
The 1966 spring migration at Regina followed a rather curious pattern: some of the first migrants arrived very early, but an unusually cold April slowed down later movements. A 48-hour snow storm (April 26-27) brought nine inches of snow, and the last five days of the month had freezing temperatures. The delayed migration is reflected in the May count. One conspicuous example is the large number of Harris' Sparrows (251) which have usually reached a peak earlier. The fact that 35 Loggerhead Shrikes were seen (compare 16 on May 15, 1965) also suggests a belated migration, for in most of the Regina area breeding shrikes are not especially common. The rather large total of 10 Sparrow Hawks (compare 1 seen May 15, 1965) may have a similar explanation, although the presence of a pair at a location where they were known to nest in 
1965 , and the several sightings by the Binnies of a pair near the Provincial Correctional Institution farm, suggest the possibility of several pairs nesting in the Regina area in 1966.

Conspicuous by their absence were the Catbird and Eastern Kingbird, and only three Baltimore Orioles were reported. In a normal year, these species would be expected to be more numerous on the May count (compare 1965 totals).

Counts made on the same day by geographically separated areas will help to chart the spring migration in Saskatchewan. This year, for example, the abundance of Rufous-sided Towhees in the Saskatoon area (where many, of course, would remain as residents) eclipses our Regina count of three, but the fact of real interest in mapping their movement is that towhees were common in Regina a few days before this date!

One of the really spectacular sights of the May count in the Regina area is always the migration of Lapland Longspurs. They were seen again this year in thousands by most of the parties, moving restlessly over fields or rising in clouds into the air. Through the Regina plains, these migrant longspurs move in several waves - we always watch for the first large flocks in late March, and they are always to be seen again in great numbers in May. The contrast between the largely-winter plumage of the first males and the full breeding plumage of the last migrants is striking. Meanwhile the resident longspurs have established themselves on territory, so the parties of the May count had the opportunity of seeing great waves of migrant Laplands while also observing male Chestnut-collared and McCowns in flight songs on their breeding grounds.

Species List (figures in brackets to indicate number seen May 15, 1965):

Red-necked Grebe, 1 (2) ; Horned Grebe, 46 (19); Eared Grebe, 46 (135); Western Grebe, 140 (24); Pied-billed Grebe, 3 (3): Great Blue Heron, 5 (5) ; Black-crowned Night Heron, 4 (3) ; Mute Swan, 4 (5); Whistling Swan, 10 (11); Canada Goose, 232 '-15 young (331); Mallard, 408 (293); Gadwall, 80 (71); Pintail, 224 (185) ; Green-winged Teal, 45 (13) ; Bluewinged Teal, 280 (157); American Widgeon,
167 (83) ; Shoveler, 237 (85) ; Redhead, 14 (53) : Ring-necked Duck, 3 (2) ; Canvasback, 69 (78) ; Lesser Scaup, 495 (213) ; Bufflehead, 3 (3) ; Ruddy Duck, 59 (61) ; Red-tailed Hawk, 4 (11) ; Swainson's Hawk, 5 (5) ; Rough-legged Hawk, 1; Ferruginous Hawk, 2 ; Marsh Hawk, 9 (23) ; Sparrow Hawk, 10 (1)) Ruffed Grouse, 1 (0); Gray Partridge, 4 (11); Sora, 5 (16); American Coot, 106 (311); Semipalmated Plover, 17 (3) ; Killdeer, 145 (153) ; American Golden Plover, 36 (62); Black-bellied Plover, 11 (0); Common Snipe, 3 (0); Upland Plover, 2 (0); Spotted Sandpiper, 14 (19); Willet, 43 (49) ; Greater Yellowlegs, 1 (1) ; Lesser Yellowlegs, 83 (12); Pectoral Sandpiper, 135 (137) ; White-rumped Sandpiper, $2(0)$; Baird's Sandpiper, 104 (266); Lsast Sandpiper, 119 (36): Long-billed Dowitcher, 29 (38); Stilt Sandpiper, $2(0)$; Semipalmated Sandpiper, 74 (10); Marbled Godwit, 25 (25); Hudsonian Godwit, 2 (2) ; Sanderling, 15 (12) ; American Avocet, 63 (30); Wilson's Phalarope, 67 (43); Northern Phalarope, $2(0)$; California Gull, 7 (2); Ring-billed Gull, 106 (78) ; Franklin's Gull, 10 (24); Common Tern, 74 (81); Black Tern, 60 (375) ; Rock Dove, 76 (64) ; Mourning Dove, 60 (126); Great Horned Owl, 5 (10); Burrowing Owl, 2 (0); Boreal Owl, $1(0)$; Belted Kingtisher, $6 \quad(7)$; Yellow - shafted Flicker, 27 (21); Yellow bellied Sapsucker, 5 (1); Downy Woodpecker, 1 (2); Western Kingbird, 2 (44) ; Say's Phoebe, 1 (2) ; Least Flycatcher, 16 (39); Horned Lark, 337 (900); Tree Swallow, 52 (48); Bank Swallow, 2 (29); Rough-winged Swallow, $1(0)$; Barn Swallow, 41 (50); Purple Martin, 44 (35); Black-billed Magpie, 29 (55) ; Common Crow, 204 (193); Black-capped Chickadee, 2 (0); Red-breasted Nuthatch, 21 (0); Brown Creeper, $3(0)$; House Wren, 1 (16); Brown Thrasher, 13 (70) ; Robin, 268 (164) ; Hermit Trush, 1 (3); Swainson's Thrush, 158 (53); Gray-cheeked Thrush, 76 (15); Veery, 12 (15) ; Ruby-crowned Kinglet, 4 (1); Water Pipit, $3(0)$; Sprague's Pipic, 2 (5); Loggerhead Shrike, 35 (16); Starling, 43 (28) ; Solitary Vireo, $1(0)$; Philadelphia Vireo, 1 (2); Warbling Vireo, 7 (25); Black-and-white Warbler, 5 (4); Tennessee Warbler, $10(2)$; Orange-crowned Warbler, 50 (13); Yellow Warbler, 61 (40); Magnolia Warbler, 2 (1) ; Myrtle Warbler, 266 (132) ; Audubon's Warbler, $2(0)$; Black-throated Green Warbler, $3(0)$; Blackpoll Warbler, 13 (18); Palm Warbler, 7 (5) ; Ovenbird, 4 (8); Northern Waterthrush, $13(50)$; Connecticut Warbler, 1 (0); Yellowthroat, 1 (1); Wilson's Warbler, $2(0)$; American Redstart, $2(0)$; House Sparrow, $510+(1000+)$; Western Meadowlark, 358 (307); Yellow-headed Blackbird, 47 (227) ; Redwinged Blackbird, 1086 †-(1077); Baltimore Oriole, 3 (29) ; Brewer's Blackbird, 469 (442); Common Grackle, 167 (118); Brown - headed Cowbird, 169 (146) ; Rosebreasted Grosbeak, 10 (13) : Purple Finch, 11 (1) ; Rufous-sided Towhee, 3 (9) ; Lark Bunting, 4 (13) ; Savannah Sparrow, 48 (79); Baird's Sparrow, 1 (1) ; Vesper Sparrow, 60 (53) ; Lark Sparrow, 2 (2); Slate-colored Junco, 8 (2) ; Chipping Sparrow, 141 (542) ; Clay-colored Sparrow, 148 (485); Harris' Sparrow, 251 (33); White-crowned Sparrow, 204 (92) ; Golden-crowned Sparrow, 1 (0); White-throated Sparrow, 114 (142); Lincoln's Sparrow, 34 (47) ; Song Sparrow, 27 (35); McCown's Longspur, $248+(46)$; Lapland Longspur, $11744+(10,000+)$; Chestnut-collared Longspur, 46 (310) ; Snow Bunting, 2 (0).

Count totals compiled by Hugh and Joyce Smith, Regina; reported by by Margaret Belcher, Regina. 